\title{
The use of a radiotelemetric ruminal bolus to detect body temperature changes in lactating dairy cattle
}

\author{
O. AlZahal,, ${ }^{*}$ H. AlZahal, ${ }^{*}$ M. A. Steele, ${ }^{*}$ M. Van Schaik, ${ }^{\star}$ I. Kyriazakis,† T. F. Duffield,‡ and B. W. McBride ${ }^{\star 1}$ \\ ${ }^{*}$ Department of Animal and Poultry Science, and \\ $\ddagger$ Department of Population Medicine, University of Guelph, Guelph, N1G 2W1, Canada \\ †School of Agriculture, Food, and Rural Development, Newcastle University, Newcastle upon Tyne, NE1 7RU, UK
}

\begin{abstract}
The objective of this study was to validate the efficacy of a radiotelemetric bolus (RTB) to detect changes in ruminal temperature resulting from (1) systemic illnesses that are associated with febrile responses and (2) subacute ruminal acidosis (SARA). Eight rumenfistulated, lactating Holstein cows $(586 \pm 37 \mathrm{~kg}$ of body weight, $106 \pm 18 \mathrm{~d}$ in milk) were used in a replicated 4 $\times 4$ Latin square design with a $2 \times 2$ factorial arrangement. Each period consisted of $21 \mathrm{~d}$. The factors were 2 diets, a moderate forage:concentrate [MFC; $52: 48 ; \%$ of dry matter (DM)] or a high forage:concentrate (HFC; $65: 35, \%$ of DM) total mixed ration, and a challenge with a single intramammary injection of lipopolysaccharide (LPS; $100 \mu \mathrm{g}$ derived from Escherichia coli 0111:B4) or no LPS (sterile saline). Thus, the 4 resulting treatments were (1) MFC with LPS challenge, (2) MFC with saline, (3) HFC with LPS challenge, and (4) HFC with saline. Cows were fed at 0800 and 1400 $\mathrm{h}$ daily. Cows received the intramammary injections at $0900 \mathrm{~h}$ of d 21 . Ruminal $\mathrm{pH}$ and ruminal temperature were also measured on d 21 every minute via an indwelling logging system that resided in the ventral sac of the rumen and via a radiotelemetric bolus that resided in the reticulum. Vaginal temperature was also recorded every minute via temperature loggers. Prior to LPS injection, the duration of rumen $\mathrm{pH}$ below 5.6 (indicative of SARA) was higher in cows receiving MFC than cows receiving HFC $(148 \pm 24$ and $62 \pm 24 \mathrm{~min} / \mathrm{d}$, respectively). The temperature measured at the same time via RTB was higher for MFC than $\mathrm{HFC}$ cows $\left(167 \pm 21\right.$ vs. 104 vs. $21 \mathrm{~min} / \mathrm{d}$ above $38.8^{\circ} \mathrm{C}$, respectively). The following day, cows challenged with LPS showed signs of mastitis within the injected quarters, depressed DM intake, decreased milk yield, and a peak vaginal temperature of $41.3 \pm 0.1^{\circ} \mathrm{C} 5.5 \mathrm{~h}$ after the LPS injection. The RTB system successfully detected a
\end{abstract}

Received October 18, 2010.

Accepted March 13, 2011.

${ }^{1}$ Corresponding author: bmcbride@uoguelph.ca fever response parallel to that measured by the vaginal loggers but temperature peak detected by RTB was, on average, $0.5^{\circ} \mathrm{C}$ lower than that detected by the vaginal logger. Although the RTB system was able to detect a temperature response to the diet effect before LPS challenge, it was unable to detect this effect during the LPS challenge, likely because cows receiving the LPS challenge had decreased feed consumption. In conclusion, radiotelemetry has the potential to improve the detection of SARA and fever on farm.

Key words: radiotelemetry, body temperature, subacute ruminal acidosis, dairy cow

\section{INTRODUCTION}

Radiotelemetry has been used in research for many decades to monitor numerous physiological parameters such as respiration rate, heart rate, and body temperature (BT) in animals (Bligh and Heal, 1974). Measuring $\mathrm{BT}$ via radiotelemetry has received much attention from researchers because of its potential in detecting health events in the field, and subsequently improving animal health, performance, and welfare. Extending the use of radiotelemetry to commercial livestock production, however, has been limited due to several issues such as sensor stability, battery life, and cost of equipment. The use of radiotelemetry to measure BT has become more feasible by advancements in both sensor and battery technologies. Sensors can be implanted via a simple surgical procedure in the vagina (Araki et al., 1984), udder (Lefcourt et al., 1986), or abdominal cavity (Brown-Brandl et al., 2003) of cattle. More recently, sensors for intraruminal insertion through the esophagus (boluses) have been developed as a noninvasive alternative to surgery (Dye et al., 2007; Ipema et al., 2008; Sims et al., 2008; Small et al., 2008; Timsit et al., 2010). Dye et al. (2007) reported radiotelemetric boluses (RTB) have the potential to detect BT increases due to bovine respiratory disease (BRD) and bovine viral diarrhea (BVD) in beef cattle. Cattle exposed to BRD or BVD showed an increase in ruminal temperature that ranged from 0.54 to $1.44^{\circ} \mathrm{C}$ 
(Dye et al., 2007) compared with nonexposed animals. Moreover, Small et al. (2008) demonstrated that RTB was efficacious in detecting fever in heifers induced by i.v. injection of LPS (Escherichia coli, $25 \mu \mathrm{g} / \mathrm{kg}$ of 93\% of BW). Recently, Timsit et al. (2010), in a field study, showed that RTB was able to detect BRD in growing bulls before the onset of clinical signs of the disease. Additionally, they showed that rumen boluses improved the detection of BRD in young beef bulls by $17 \%$ over visual appraisal.

Microbial fermentation in the rumen generates heat as a by-product (Hungate, 1966). Ruminal temperature was documented to exceed rectal temperature (Dale et al., 1954; Noffsinger et al., 1961; Campos Neto et al., 1978), likely due to the action of microbial fermentation. Our studies (AlZahal et al., 2008, 2009b) have demonstrated that ruminal temperature was negatively correlated with ruminal $\mathrm{pH}(\mathbf{R p H})$. Nonfebrile cows offered diets rich in rapidly fermentable grains had a post-feeding depression in $\mathrm{RpH}$ representative of SARA (below 5.6), and had a concurrent increase in ruminal temperature exceeding $40^{\circ} \mathrm{C}$ (AlZahal et al., 2008, 2009b). Therefore, changes in ruminal temperatures can be used to detect SARA and this can potentially be achieved through the use of RTB. However, it is yet unknown whether the technology can differentiate between ruminal temperature changes that are due to SARA or due to systemic responses. The objective of this study was to validate the efficacy of an RTB to detect changes in ruminal temperature resulting from (1) systemic illnesses that are associated with febrile responses and (2) SARA.

\section{MATERIALS AND METHODS}

\section{Animals, Experimental Treatments, and Feeding}

Eight rumen-fistulated, lactating Holstein cows $(586 \pm 37 \mathrm{~kg}$ of BW, $106 \pm 18 \mathrm{DIM})$ were used in a replicated $4 \times 4$ Latin square design with a $2 \times$ 2 factorial arrangement. The factors were 2 diets, a moderate forage:concentrate (MFC; $52: 48, \%$ of DM) or a high forage:concentrate (HFC; $65: 35, \%$ of DM) TMR (one that leads to SARA and one that does not, respectively), and a challenge with an intramammary infusion of LPS or not (one that induces fever and one that does not, respectively). Thus, the 4 resulting treatments were (1) MFC TMR with LPS challenge, (2) MFC TMR with no LPS challenge, (3) HFC TMR with LPS challenge, and (4) HFC TMR with no LPS challenge. Each Latin square period lasted for $21 \mathrm{~d}$.

The TMR (MFC and HFC) were fed twice daily in equal amounts at 0800 and $1400 \mathrm{~h}$. The amount fed was adjusted weekly based on average DMI of the previous week to allow a maximum of $5 \mathrm{~kg} / \mathrm{d}$ of orts (as-fed basis). Ingredients and chemical analyses of MFC and HFC TMR are presented in Table 1 . The chemical analyses of MFC and HFC TMR agreed closely with formulation targets. The HFC diet was formulated to provide a large amount of fiber to sustain an optimal $\mathrm{RpH}$. Contrastingly, the MFC diet contained a sufficient amount of fiber to maintain DMI and milk production and yet included an ample amount of wheat and barley $(28 \%$ of DM), which are rapidly and extensively fermented in the rumen, to induce a depression in ruminal $\mathrm{pH}$. A similar feeding protocol successfully induced SARA in previous studies (AlZahal et al., 2009a, 2010). Cows that were assigned the MFC treatment were gradually adapted to their grain level. The cows had access to water ad libitum.

The cows were housed in a tie-stall facility at the Ponsonby Dairy Research Station (University of Guelph, Guelph, Ontario, Canada). The University of Guelph Animal Care Committee approved their use for this experiment.

\section{Experimental Measures and Samples Analyses}

Ten milliliters of $0.85 \%$ sterile saline solution containing either 0 or $100 \mu \mathrm{g}$ of LPS, derived from E. coli

Table 1. Ingredient composition and chemical analyses of moderate forage:concentrate (MFC) and high forage:concentrate (HFC) TMR

\begin{tabular}{lrr}
\hline Item & HFC & MFC \\
\hline Ingredient (\% of DM) & & \\
Corn silage & 29.9 & 23.9 \\
Alfalfa silage & 29.9 & 23.9 \\
Straw & 6.2 & 5.0 \\
Corn (cracked) & 10.0 & 0.0 \\
Wheat and barley pellets & 0.0 & 28.0 \\
Protein supplement ${ }^{1}$ & 23.9 & 19.1 \\
Chemical composition (\% of DM) & 38.3 & \\
DM (\%) & 17.4 & 43.2 \\
CP (N $\times$ 6.25) & 5.2 & 16.0 \\
Soluble protein & 23.5 & 4.2 \\
ADF & 38.5 & 20.1 \\
NDF & 3.0 & 35.2 \\
Ether extract $_{\text {Ash }}$ & 8.5 & 7.5 \\
NFC $^{2}$ & 32.6 & 39.0 \\
Starch $^{3}$ & 16.9 & 25.3 \\
NE $_{\mathrm{L}}{ }^{4}$ (Mcal/kg) & 1.5 & 1.6 \\
\hline
\end{tabular}

${ }^{1}$ Contained (\% as-fed basis): $48 \%$ soybean meal, 29.1; high-protein corn gluten meal, 5.0; canola meal, 15.0; roasted soybean (whole), 15.0; fish meal (herring), 2.5; beet pulp, 5.0; dried distillers grain, 12.5; calcium carbonate (limestone), 3.6; monocalcium phosphate, 2.0; tallow, 2.0; sodium sesquicarbonate, 2.5; salt, 2.3; molasses (in pelleter), 2.0; magnesium oxide, 0.7; Organic Ruminant Micro Premix (Floradale Feed Mill Limited; Floradale, ON, Canada), 0.5; and sulfur flour (99.5\%), 0.1.

${ }^{2} \mathrm{NFC}=100-(\mathrm{NDF}+\mathrm{CP}+$ ether extract + ash $)$.

${ }^{3}$ Analyzed according to Hall (2000).

${ }^{4}$ Estimated using CPM-Dairy v 3.0.8 (Miner Institute, Chazy, NY) using the chemical analysis of feed ingredients. 
0111:B4 (Sigma Chemical Co., St. Louis, MO), was injected using a sterile plastic syringe directly into the mammary gland at $0900 \mathrm{~h}$ on d 21 of each experimental period. Injections across periods were alternated between front-left and front-right quarters of the udder. Bannerman et al. (2003) demonstrated that this challenge protocol induced a febrile response characterized by an increased rectal temperature, which peaked at $41.5 \pm 0.13^{\circ} \mathrm{C}$ within $6 \mathrm{~h}$ of the LPS injection and returned to normal within $10 \mathrm{~h}$ of the injection.

Each cow was equipped with a mobile recording system (conventional system) that consisted of an electrode that resided in the ventral sac of the rumen and connected to a data logger mounted on the animal's back as described by AlZahal et al. (2007b). The conventional system continuously recorded both ventral $\mathrm{RpH}$ and ventral ruminal temperature $\left(\mathbf{T}_{\mathbf{R}}\right)$ every min during d 20 and 21 of each period. Each cow was also equipped with an RTB $(3 \mathrm{~cm}$ in diameter and $8.5 \mathrm{~cm}$ in height,120 g in weight; SmartStock LLC, Pawnee, $\mathrm{OK}$ ) that was inserted into the ventral sac of the rumen through the fistula. The telemetric system was described in detail by AlZahal et al. (2009b). The RTB was set to broadcast the temperature $\left(\mathbf{T}_{\mathbf{R T B}}\right)$ every min during d 20 and 21 of each period. To confirm that the LPS challenge induced a rise in BT, vaginal temperature $\left(\mathbf{T}_{\mathbf{V}}\right)$ for each individual cow was monitored every min via a data logger (Part \# U22-001; HOBO Datalogger Co., Bourne, MA) during d 20 and 21 of each period. Ambient temperature was monitored every hour using a temperature logger (Part \# U23-002; Datalogger Co.).

Feed intake and milk yield were monitored daily throughout the experiment. During d 21 (LPS challenge day) feed intake was assessed at the first $12 \mathrm{~h}$ (from 0800 to $2000 \mathrm{~h}, 12-\mathrm{h}$ DMI). Total mixed ration samples from each dietary treatment and ort samples from each individual cow were collected 3 times per week and frozen at $-20^{\circ} \mathrm{C}$ until analysis. The TMR and orts samples were dried for $48 \mathrm{~h}$ in a forced-air oven at $60^{\circ} \mathrm{C}$ to determine the DM content for that week. At the end of the experiment, dried TMR samples were analyzed at Agri-Food Laboratory (Guelph, Ontario, Canada) for $\mathrm{CP}$, ash, ether extract, ADF (procedures 4.2.08, 4.1.10, 4.5.01, and 4.6.03; respectively; AOAC, 1996), NDF (Mertens et al., 2002), soluble CP (Licitra et al., 1996), and starch concentration (Hall, 2000). Cows were milked twice daily at 0500 and $1500 \mathrm{~h}$, and milk samples were collected 2 times from morning and afternoon milkings during the third week of each period (d 17 and 20). The milk yield after LPS infusion was the summation of the 1500-h milking of the same day and the 0500-h milking of the next morning. Milk samples were pooled by cow by day based on produc- tion, before being pooled by week using equal daily proportions, and submitted to Laboratory Services Division (Guelph, Ontario, Canada) for composition analysis using a near-infrared analyzer (Foss System 4000; Foss Electric, Hillerød, Denmark).

\section{Statistical Analysis}

Data collected during the LPS injection day (d 21), including RpH, $\mathrm{T}_{\mathrm{R}}, \mathrm{T}_{\mathrm{RTB}}, \mathrm{T}_{\mathrm{V}}, \mathrm{DMI}, 12-\mathrm{h} \mathrm{DMI}$, and milk yield were analyzed using PROC MIXED of SAS (SAS Institute, 2004) using the following model:

$$
\mathrm{Y}_{\mathrm{ijkl}}=\mu+\mathrm{R}_{\mathrm{i}}+\mathrm{C}_{\mathrm{j}}+\mathrm{D}_{\mathrm{k}}+\mathrm{F}_{\mathrm{l}}+(\mathrm{D} \times \mathrm{F})_{\mathrm{kl}}+\varepsilon_{\mathrm{ijkl}},
$$

where $Y_{\mathrm{ijk}}$ is the dependent variable, $\mu$ is the overall mean, $R_{i}$ is the fixed effect of row or period ( $i=1,2$, $3,4), \mathrm{C}_{\mathrm{j}}$ is the fixed effect of column or cow $(\mathrm{j}=1, \ldots$ . , 8), $\mathrm{D}_{\mathrm{k}}$ is the fixed effect of diet $(\mathrm{k}=1,2), \mathrm{F}_{1}$ is the fixed effect of LPS injection $(\mathrm{l}=1,2),(\mathrm{D} \times \mathrm{F})_{\mathrm{kl}}$ is the effect of the interaction of diet by LPS injection $(\mathrm{kl}=$ $1,4)$, and $\varepsilon_{\mathrm{ijkl}}$ is the random residual error. Pairwise comparisons were performed using the PDIFF statement of SAS.

Data collected during the third week of each experimental period before LPS injection day, including $\mathrm{RpH}$, $T_{R}, T_{R T B}, T_{V}$ (all collected during d 20), average daily DMI and milk yield (collected during d 15 through 20), and milk composition (pooled samples for d 17 and 20) were analyzed using the previous model, excluding the LPS and the interaction terms. Comparisons between methods of temperature recording were performed using a paired TTEST of SAS.

\section{RESULTS AND DISCUSSION}

\section{Prior to LPS Challenge}

During d 15 through 20, no difference $(P \geq 0.05)$ was observed in DMI between treatments $(25.2 \pm 0.32$ vs. $24.7 \pm 0.32 \mathrm{~kg} / \mathrm{d}$, MFC vs. HFC, respectively). Nonetheless, cows receiving the MFC had greater milk yield, greater milk protein percentage, and greater lactose percentage than cows receiving the HFC $(34.8 \pm 0.42$ vs. $33.5 \pm 0.42 \mathrm{~kg} / \mathrm{d}, 3.33 \pm 0.01$ vs. $3.26 \% \pm 0.01$, and $4.77 \pm 0.01$ vs. $4.72 \% \pm 0.01$, respectively; $P<$ $0.05)$. The difference in milk yield between treatments was likely a result of the difference in energy density between diets (see Table 1). The slight differences in milk protein and lactose likely reflected the difference in milk yield between treatments. No effect of treatments on milk fat characteristics existed $(P \geq 0.05)$. Nonetheless, milk yield and composition levels for both treatments are considered within the acceptable ranges 
for Holstein cows in Ontario, Canada (Dairy Farmers of Ontario, 2010).

During d 20 (the day before the LPS challenge), cows receiving the MFC diet had significantly lower $\mathrm{RpH}$ characteristics than cows receiving the HFC diet. This difference in $\mathrm{RpH}$ was characterized by lower mean $\mathrm{pH}$ $(6.03 \pm 0.03$ vs. $6.22 \pm 0.03)$, lower minimum $\mathrm{pH}(5.39$ \pm 0.04 vs. $5.63 \pm 0.04)$, and longer duration $(\mathrm{min} / \mathrm{d})$ of $\mathrm{RpH}$ below 6.0 (676 \pm 56 vs. $296 \pm 56), 5.8$ (373 \pm 42 vs. $142 \pm 42)$, and $5.6(148 \pm 24$ vs. $62 \pm 24)$ for cows receiving the MFC compared with cows receiving the HFC, respectively $(P<0.05)$. Cows receiving the MFC diet spent $148 \pm 24 \mathrm{~min} / \mathrm{d}$ below $\mathrm{pH}$ 5.6. Previous studies have showed that a severe SARA response can occur when $\mathrm{RpH}$ drops below 5.6 for more than 3 $\mathrm{h} / \mathrm{d}$; therefore, cows in this study were considered under a moderate SARA condition (AlZahal et al., 2007a; Plaizier et al., 2008). During d 20, MFC cows had higher $(P<0.05)$ mean $\mathrm{T}_{\mathrm{R}}$, maximum $\mathrm{T}_{\mathrm{R}}$, and longer duration above threshold $38.8^{\circ} \mathrm{C}$ than the $\mathrm{HFC}$ cows $\left(38.40 \pm 0.04\right.$ vs. $38.18 \pm 0.04^{\circ} \mathrm{C}, 39.59 \pm 0.09$ vs. 39.33 $\pm 0.09^{\circ} \mathrm{C}, 461 \pm 39$ vs. $322 \pm 39 \mathrm{~min} / \mathrm{d}$; respectively). No difference $(P \geq 0.05)$ was observed in mean $\mathrm{T}_{\mathrm{RTB}}$ $\left(38.0^{\circ} \mathrm{C}\right)$ and maximum $\mathrm{T}_{\mathrm{RTB}}\left(39.0^{\circ} \mathrm{C}\right)$ between treatments; however, the $\mathrm{T}_{\mathrm{RTB}}$ of cows receiving the MFC diet spent a longer duration $(P<0.05)$ above $38.8^{\circ} \mathrm{C}$ compared with the HFC cows $(167 \pm 21$ vs. 104 vs. 21 $\mathrm{min} / \mathrm{d}$, respectively).

A previous study that used the conventional system (AlZahal et al., 2008) demonstrated that a diet that induced a depression in $\mathrm{RpH}$ (SARA) also elevated ruminal temperature in nonfebrile cows and suggested that this inverse relationship between $\mathrm{RpH}$ and ruminal temperature could be used to predict $\mathrm{RpH}$. Heat is considered a byproduct of microbial fermentation (Hungate, 1966) and, therefore, a more rapid and extensive fermentation is expected to generate more heat within the rumen during a given period of time post-feeding than a more slowly fermented high-fiber diet. Noffsinger et al. (1961) reported that ruminal temperature and rectal temperature were higher for ad libitum-fed $\left(39.66\right.$ and $\left.40.11^{\circ} \mathrm{C}\right)$ compared with fasted sheep (38.94 and $38.94^{\circ} \mathrm{C}$, respectively). Also, in another study, similar increases post-feeding in ruminal and rectal temperatures were observed in fistulated buffalo and oxen (Bhattacharyya, 1978). In addition, Campos Neto et al. (1978) demonstrated that Zebu cattle fed concentrate had higher ruminal temperature than animals fed only grass $\left(41.8\right.$ vs. $\left.40.53^{\circ} \mathrm{C}\right)$ and concluded that "type of diet can affect ruminal temperature." Campos Neto et al. (1978) did not evaluate the effect of diet on rectal temperature. The authors are not aware of any studies that examined the effect of heat of microbial fermenta- tion generated within the rumen on BT. In the current study, no effect of diet on mean daily $\mathrm{T}_{\mathrm{V}}$ was observed.

Recently, AlZahal et al. (2009b) validated an RTB system, and they showed that RTB can detect differences in ruminal temperature that are a result of diet type. In the validation study, AlZahal et al. (2009b) tethered the RTB to the electrode of the conventional system, which was positioned in the ventral sac of the rumen to exclude the bias caused by the location of the bolus within the rumen. In the current investigation, the RTB was not tethered to reflect on-farm conditions. At the end of the current study, all of the RTB were located through rumen cannula in the reticulum. Therefore, it is speculated that the RTB, given their weight, may reside in the reticulum, and that the measured $\mathrm{T}_{\mathrm{RTB}}$ represents the temperature of the reticular region. The temperature parameters, as obtained by the RTB in the current study, were consistently lower $(P<0.05)$ than $\mathrm{T}_{\mathrm{R}}$. This can be explained by lower temperatures detected in the reticulum, likely because of the influence of water drinking (Bewley et al., 2008; Dye and Richards, 2008). The differences in $\mathrm{T}_{\mathrm{RTB}}$ between treatments, resulting from diet effects, were tested as the durations $(\mathrm{min} / \mathrm{d})$ above specific thresholds ranging from 38.2 to $40.0^{\circ} \mathrm{C}$. The RTB were able to detect a longer duration of reticulum temperature above $38.8^{\circ} \mathrm{C}$ in MFC cows compared with the HFC cows, which suggests that the threshold $38.8^{\circ} \mathrm{C}$ could be of a diagnostic significance for the detection of SARA in nonfebrile animals.

\section{During LPS Challenge, $d 21$}

Vaginal temperature characteristics are presented in Table 2. No effect of diet on $\mathrm{T}_{\mathrm{V}}$ was observed. Approximately 3 to $4 \mathrm{~h}$ after the injection, all LPS-challenged cows exhibited signs of mastitis, which included udder swelling and abnormal milk characteristics within the infused quarter. Vaginal temperature for LPS-challenged cows, regardless of diet type, started to increase $2 \mathrm{~h}$ after the LPS injection and peaked after $5.5 \mathrm{~h}$ at 41.31 $\pm 0.39^{\circ} \mathrm{C}$ (mean $\pm \mathrm{SD}$; Figure 1 ). Body temperature returned to normal approximately $10 \mathrm{~h}$ after injection. The changes in $\mathrm{BT}$ in this experiment in response to LPS challenge agree closely with temperatures observed by Bannerman et al. (2003) in a similar study.

Cows challenged with LPS were completely off feed during the peak temperature hours $\left(3\right.$ to $\left.4 \mathrm{~h}>40.0^{\circ} \mathrm{C}\right)$. Cows returned to feeding after the peak fever interval. Cows challenged with LPS consumed $23 \%$ less feed by $2000 \mathrm{~h}$ of the same day than cows injected with saline. However, this difference was decreased by the next morning to only $10 \%$, indicating that the LPS- 
Table 2. Least squares means for DMI, milk yield, ruminal $\mathrm{pH}$, and ruminal temperature $\left(\mathrm{T}_{\mathrm{R}}\right)$ obtained by the conventional system, vaginal temperature $\left(\mathrm{T}_{\mathrm{V}}\right)$ obtained by vaginal logger, and reticulum temperature obtained by telemetric bolus $\left(\mathrm{T}_{\mathrm{RTB}}\right)$ during d 21 of each Latin square

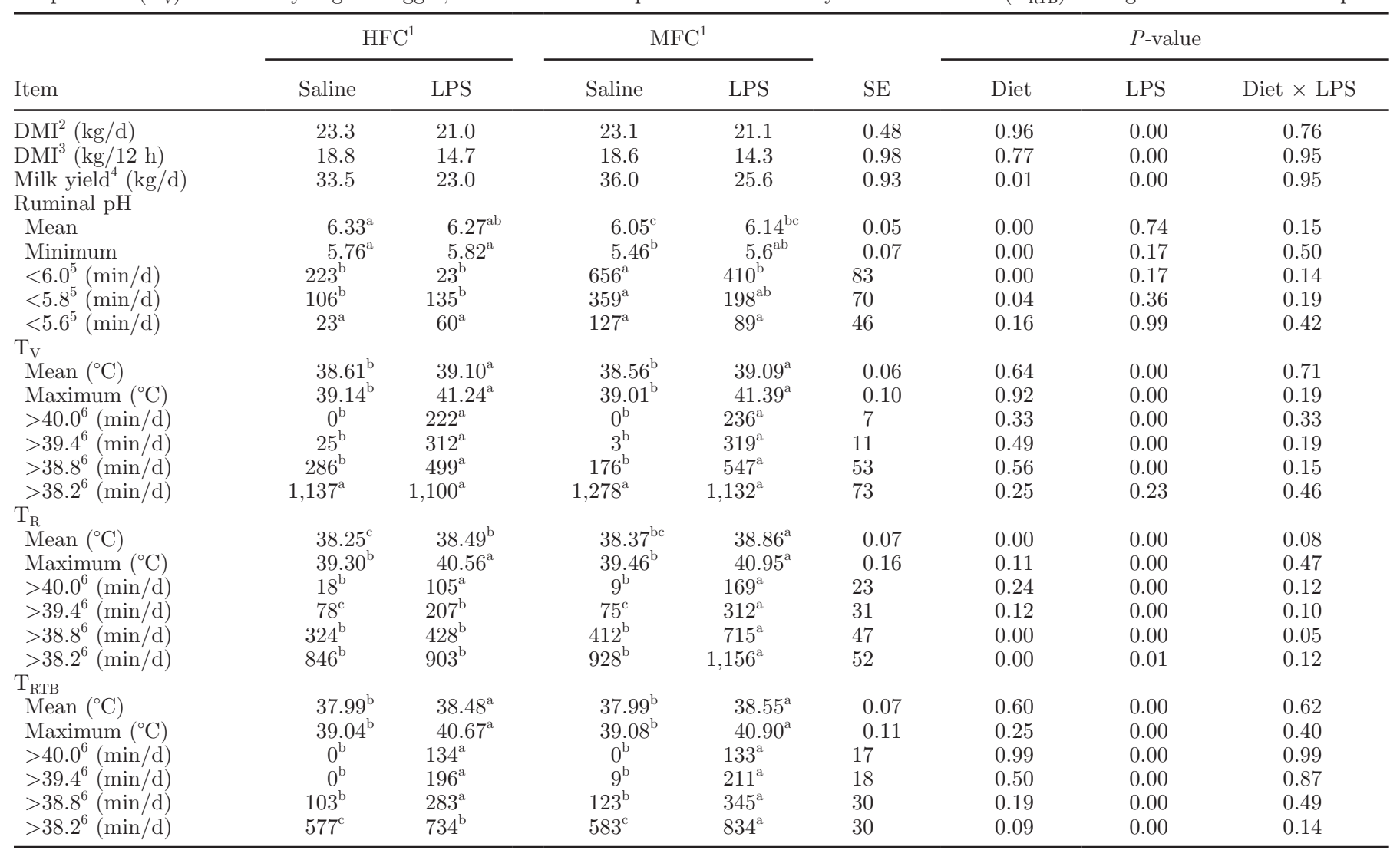

${ }^{\mathrm{a}-\mathrm{c}}$ Means within a row with the same superscript letter are not significantly different $(P>0.05)$.

${ }^{1} \mathrm{HFC}=$ high forage:concentrate TMR (65:35, DM basis); MFC = moderate forage:concentrate TMR (52:48, DM basis).

${ }^{2} \mathrm{DMI}$ from 0800 through $0800 \mathrm{~h}$ of next day.

${ }^{3}$ DMI from 0800 through $2000 \mathrm{~h}$ during of same day (12-h DMI).

${ }^{4}$ Milk yield during p.m. milking on d 21 plus a.m. milking of the next day.

${ }^{5}$ Length of time $\mathrm{pH}$ was below a given $\mathrm{pH}$ threshold.

${ }^{6}$ Length of time temperature was above a given threshold.

challenged cows had the opportunity during the night to compensate for the off-feed hours during fever (Table $2)$. A depression in intake was also observed with heifers that were challenged with LPS (E. coli 0111:B4, 2 $\mu \mathrm{g} / \mathrm{kg}$ of BW i.v.; Steiger et al., 1999). Cows challenged with LPS had lower milk yield (Table 2) as a result of milk loss from the inflamed udder quarter (approximately $25 \%$ ), but returned to normal within $48 \mathrm{~h}$ (data not shown). Ruminal $\mathrm{pH}$ characteristics during the LPS challenge are presented in Table 2 . Cows receiving the MFC diet had lower mean $\mathrm{RpH}$ and spent longer durations (min/d) of $\mathrm{RpH}$ below 6.0 and 5.8 compared with cows receiving the HFC diet.

The conventional system was able to detect changes in ruminal temperature $\left(\mathrm{T}_{\mathrm{R}}\right)$ that resulted from the LPS challenge and diet $(P<0.05$; Table 2$)$. Furthermore, the increase in $T_{R}$ resulting from the LPS challenge was of a much greater magnitude compared with that of the diet effect. Ruminal temperature during fever peaked on average between 40.5 to $41.0^{\circ} \mathrm{C}$ and remained above $40.0^{\circ} \mathrm{C}$ for approximately $2 \mathrm{~h}$, whereas the average daily maximum due to the dietary effect was below $39.5^{\circ} \mathrm{C}$. An additive effect was observed for both LPS and diet on the duration $(\mathrm{min} / \mathrm{d})$ that $\mathrm{T}_{\mathrm{R}}$ was above $38.8^{\circ} \mathrm{C}$ $(P<0.05$, Table 2$)$; the MFC + LPS cows spent the longest time $(715 \mathrm{~min} / \mathrm{d})$ above $38.8^{\circ} \mathrm{C}$. The temperature thresholds ranging from 38.8 to $39.4^{\circ} \mathrm{C}$ have been shown to capture changes in ruminal temperature that result from SARA (AlZahal et al., 2008, 2009b) in nonfebrile cows. The telemetric boluses $\left(\mathrm{T}_{\mathrm{RTB}}\right)$ were able to effectively capture the febrile responses during the LPS injection in a fashion that paralleled $T_{V}$ and $T_{R}$ responses; however, the boluses were unable, during the LPS challenge, to detect a diet effect (Table 2). This 


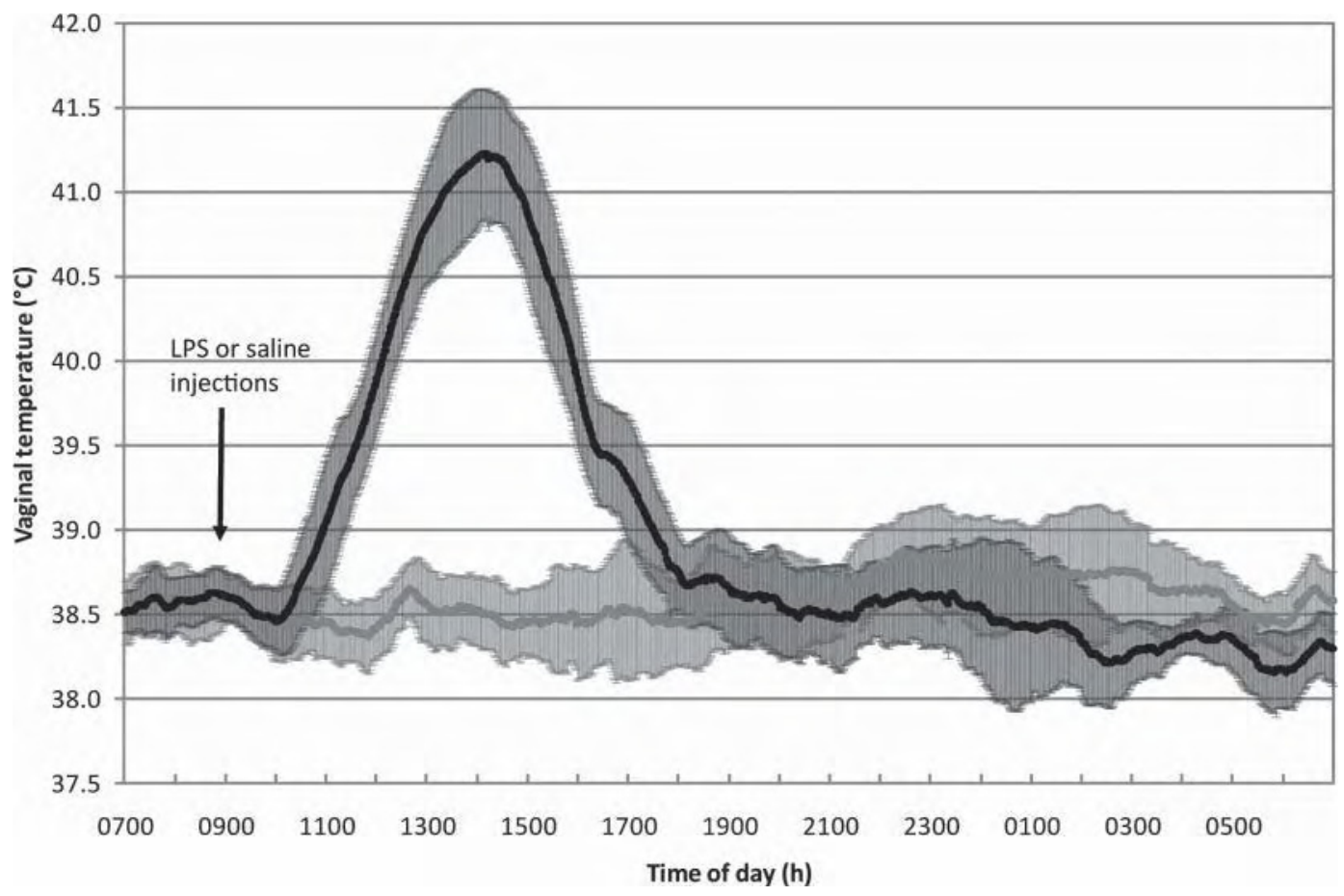

Figure 1. Twenty-four-hour recording of vaginal temperature during d 21 of cows received intramammary injection of LPS (black marker) or saline (gray marker). Each point $(\mathrm{n}=16)$ represents average vaginal temperature recorded during a given minute. The error bars represent standard deviation. Lipopolysaccharide or saline injections were administered at $0900 \mathrm{~h}$, as depicted by the arrow.

is likely because of the decrease in feed consumption observed in cows receiving the LPS challenge.

The $\mathrm{T}_{\mathrm{RTB}}$ peaked at $40.78 \pm 0.11^{\circ} \mathrm{C}$ during the LPS challenge, which was not significantly different from $\mathrm{T}_{\mathrm{R}}$ peak (40. $\left.75 \pm 0.16, P \geq 0.05\right)$. Nonetheless, both $\mathrm{T}_{\mathrm{R}}$ and $\mathrm{T}_{\mathrm{RTB}}$ peaked lower than $\mathrm{T}_{\mathrm{V}}(41.31 \pm 0.10, P$ $\geq 0.05)$. The daily mean $\mathrm{T}_{\mathrm{RTB}}$ was lower $(P<0.05)$ than the mean $\mathrm{T}_{\mathrm{R}}$ and $\mathrm{T}_{\mathrm{V}}(P<0.05)$; these differences are believed to be because of the bolus location in the reticulum, as explained earlier. Although drinking is found to interfere with the temperature measurement in the reticulum, research has suggested that recording the temperature of the consumed water may allow to not only separate the effect of drinking events on reticular temperature but also to quantify those events and provide necessary data on drinking behavior (Dye and Richards, 2008). The temperature of drinking water was not recorded in the current experiment.

This work emphasizes that measuring ruminal temperature via radiotelemetry has the potential to detect fever and can be more practical than using vaginal or rectal telemetric devices. Measuring ruminal temperature via RTB also has the potential to detect SARA (AlZahal et al., 2009b), but only in nonfebrile animals (current study). The changes in ruminal temperature resulting from SARA occur for several hours post-feeding in response to fermentation patterns; then, ruminal temperature returns to normal (AlZahal et al., 2008), whereas the changes in ruminal temperature associated with fever may last for several days (Dye et al., 2007).

In the current experiment, cows were housed in a temperature-stable environment where indoor temperature averaged $12.0 \pm 2.0^{\circ} \mathrm{C}( \pm \mathrm{SD})$. Therefore, it is believed that these small ambient temperature fluctuations did not affect the results of this experiment. However, the effects of ambient temperature changes across seasons or geographical regions on the efficacy of SARA or fever detection are not known. Therefore, to implement the use of telemetry for the early diagnosis of fever or SARA on farm, more research is needed to understand the relationship between factors that can influence ruminal temperature. This study provided an example through which the interaction between 2 factors, LPS administration (fever) and SARA, were examined.

In conclusion, the results showed that the RTB system was able to detect the increase in BT associated with an LPS challenge. In addition it was able to detect changes in rumen temperature associated with diet composition in nonfebrile animals. However, the increase in ruminal 
temperature during the LPS-induced fever far exceeded the modest increase in ruminal temperature associated with SARA.

\section{REFERENCES}

AlZahal, O., E. Kebreab, J. France, M. Froetschel, and B. W. McBride. 2008. Ruminal temperature may aid in the detection of subacute ruminal acidosis. J. Dairy Sci. 91:202-207.

AlZahal, O., E. Kebreab, J. France, and B. W. McBride. 2007a. A mathematical approach to predicting biological values from ruminal pH measurements. J. Dairy Sci. 90:3777-3785.

AlZahal, O., M. M. Or-Rashid, S. L. Greenwood, M. S. Douglas, and B. W. McBride. 2009a. The effect of dietary fiber level on milk fat concentration and fatty acid profile of cows fed diets containing low levels of polyunsaturated fatty acids. J. Dairy Sci. 92:1108-1116.

AlZahal, O., M. M. Or-Rashid, S. L. Greenwood, and B. W. McBride. 2010. Effect of subacute ruminal acidosis on milk fat concentration, yield and fatty acid profile of dairy cows receiving soybean oil. J. Dairy Res. 77:376-384.

AlZahal, O., B. Rustomo, N. E. Odongo, T. F. Duffield, and B. W McBride. 2007b. Technical note: A system for continuous recording of ruminal pH in cattle. J. Anim. Sci. 85:213-217.

AlZahal, O., M. A. Steele, E. V. Valdes, and B. W. McBride. 2009b. Technical note: The use of a telemetric system to continuously monitor ruminal temperature and to predict ruminal $\mathrm{pH}$ in cattle. J. Dairy Sci. 92:5697-5701.

AOAC. 1996. Official Methods of Analysis. 16th ed. Association of Official Analytical Chemists, Arlington, VA.

Araki, C. T., R. M. Nakamura, G. L. Seawright, and R. R. Brown. 1984. Computerized biotelemetry system for environmental-research on dairy animals. J. Dairy Sci. 67:1047-1053.

Bannerman, D. D., M. J. Paape, W. R. Hare, and E. J. Sohn. 2003. Increased levels of LPS-binding protein in bovine blood and milk following bacterial lipopolysaccharide challenge. J. Dairy Sci. 86:3128-3137.

Bewley, J. M., M. W. Grott, M. E. Einstein, and M. M. Schutz. 2008. Impact of intake water temperatures on reticular temperatures of lactating dairy cows. J. Dairy Sci. 91:3880-3887.

Bhattacharyya, N. K. 1978. The physiological relationship between $\mathrm{pH}$, total volatile fatty acids, rumen temperature, and rumen motility. Indian J. Physiol. Allied Sci. 32:79-89.

Bligh, J., and J. W. Heal. 1974. Use of radio-telemetry in study of animal physiology. Proc. Nutr. Soc. 33:173-181.

Brown-Brandl, T. M., T. Yanagi Jr., H. Xin, R. S. Gates, R. A. Bucklin, and G. S. Ross. 2003. A new telemetry system for measuring core body temperature in livestock and poultry. Appl. Eng. Agric. 19:583-589.

Campos Neto, O., F. J. Baccari, and H. Moraes Barros. 1978. Rumen temperature of a bovine subjected to 2 different diets. Arquivos da Escola de Veterinaria, Universidade Federal de Minas Gerais 30:65-70.

Dairy Farmers of Ontario. 2010. Dairy Statistical Handbook 20092010. 26th ed. Dairy Farmers of Ontario, Mississauga, Ontario, Canada.
Dale, H. E., R. E. Stewart, and S. Brody. 1954. Rumen temperature. I. Temperature gradients during feeding and fasting. Cornell Vet. 44:368-374.

Dye, T. K., and C. J. Richards. 2008. Effect of water consumption on rumen temperature. J. Dairy Sci. 86(E-Suppl. 3):114. (Abstr.)

Dye, T. K., C. J. Richards, L. O. Burciaga-Robles, C. R. Krehbiel, and D. L. Step. 2007. Efficacy of rumen temperature boluses for health monitoring. J. Dairy Sci. 90(Suppl. 1):255-256. (Abstr.)

Hall, M. B. 2000. Starch gelatinization and hydrolysis method. Pages 29-38 in Neutral Detergent Soluble Carbohydrates, Nutritional Relevance and Analysis-A Laboratory Manual. Dept. Animal Science, Univ. Florida., Gainesville.

Hungate, R. E. 1966. The Rumen and Its Microbes. Academic Press, New York, NY.

Ipema, A. H., D. Goense, P. H. Hogewerf, H. W. J. Houwers, and H. van Roest. 2008. Pilot study to monitor body temperature of dairy cows with a rumen bolus. Comput. Electron. Agric. 64:49-52.

Lefcourt, A. M., J. Bitman, D. L. Wood, and B. Stroud. 1986. Radiotelemetry system for continuously monitoring temperature in cows. J. Dairy Sci. 69:237-242.

Licitra, G., T. M. Hernandez, and P. J. Van Soest. 1996. Standardization of procedures for nitrogen fractionation of ruminant feeds. Anim. Feed Sci. Technol. 57:347-358.

Mertens, D. R., M. Allen, J. Carmany, J. Clegg, A. Davidowicz, M. Drouches, K. Frank, D. Gambin, M. Garkie, B. Gildemeister, D. Jeffress, C. S. Jeon, D. Jones, D. Kaplan, G. N. Kim, S. Kobata, D. Main, X. Moua, B. Paul, J. Robertson, D. Taysom, N. Thiex, J. Williams, and M. Wolf. 2002. Gravimetric determination of amylase-treated neutral detergent fiber in feeds with refluxing in beakers or crucibles: Collaborative study. J. AOAC Int. 85:1217-1240.

Noffsinger, T. L., K. K. Otagaki, and C. T. Furukawa. 1961. Effect of feed and water intake on rumen and body temperatures of sheep under subtropical conditions. J. Anim. Sci. 20:718-722.

Plaizier, J. C., D. O. Krause, G. N. Gozho, and B. W. McBride. 2008. Subacute ruminal acidosis in dairy cows: The physiological causes, incidence and consequences. Vet. J. 176:21-31.

SAS Institute. 2004. SAS/STAT User's Guide. Release 9.1. SAS Inst. Inc., Cary, NC.

Sims, L. E., T. K. Dye, B. P. Holland, L. O. Burciaga-Robles, D. L. Step, R. W. Fulton, C. R. Krehbiel, and C. J. Richards. 2008. Rumen temperature monitoring for determination of health. J. Anim. Sci. 86(E-Suppl. 3):115. (Abstr.)

Small, J. A., A. D. Kennedy, and S. H. Kahane. 2008. Core body temperature monitoring with passive transponder boluses in beef heifers. Can. J. Anim. Sci. 88:225-235.

Steiger, M., M. Senn, G. Altreuther, D. Werling, F. Sutter, M. Kreuzer, and W. Langhans. 1999. Effect of a prolonged low-dose lipopolysaccharide infusion on feed intake and metabolism in heifers. J. Anim. Sci. 77:2523-2532.

Timsit, E., S. Assié, R. Quiniou, H. Seegers, C. Fourichon, and N. Bareille. 2010. Improved detection of bovine respiratory disease in the young bull with a rumen temperature bolus. Page 69 in Book of Abstracts of 61st Annu. Meeting Eur. Assoc. Anim. Prod., Heraklion, Greece. 